\section{Dragan D. Stamenković \\ Teaching Assistant University of Belgrade Faculty of Mechanical Engineering}

Vladimir M. Popović

Associate Professor University of Belgrade Faculty of Mechanical Engineering

Marko A. Tirović

Reader in Automotive Engineering Cranfield University School of Engineering

\title{
Operator's Reaction Time Prolongation Induced by Whole-Body Vibration
}

Influence of whole-body vibration on reaction times was studied on a specially developed rig, with the subjects being exposed to no vibration, and vibration frequencies of $1,5,20$ and $50 \mathrm{~Hz}$. The shortest reaction times for both, sound and visual stimuli were measured for no vibration of the seating platform. The most detrimental influence was observed at vibration frequency of $5 \mathrm{~Hz}$, with reaction times typically increasing between 50 and $70 \mathrm{~ms}$. The shortest reaction times were always measured at the beginning of tests and the longest at the end. The increases in reaction times with elapsed time were typically more pronounced when subjects were exposed to sound stimuli. Equally, under the same conditions, reaction times to sound stimuli were longer than to visual stimuli (by approx. 60 to $100 \mathrm{~ms}$ ). In all cases, changes in standard deviation values follow the same pattern as average reaction times.

Keywords: whole-body vibration, reaction time, ergonomics, safety, machinery.

\section{BACKGROUND}

The term whole-body vibration (WBV) represents the low-frequency mechanical oscillations transmitted from a vibrating surface to the human body through a broad contact area. As with most types of vibration, WBV can be useful and harmful.

WBV is considered useful when used in vibration training, where controlled short term $(<30 \mathrm{~min})$, low-amplitude $(<10 \mathrm{~mm})$ and low-frequency $(<65 \mathrm{~Hz})$ oscillations are transmitted to the human body in the treatment of osteoporosis, sarcopenia and metabolic syndrome. This type of training is also used for physical therapy, rehabilitation, in professional sports, as fitness exercise and for beauty and wellness applications [1].

Analogously to the negative effects of vibration on machinery [2], vibration exerts negative effects on operators of heavy machinery and drivers of tractors, freight and passenger vehicles, mostly in the form of occupational WBV. The most reported negative effects of such sporadic vibration acting in longer periods of time are fatigue, low-back pain (LBP) and vision problems. WBV can also negatively affect lung, abdomen, bladder and digestive and genital/urinary systems.

It is estimated that in Canada, USA and some European countries $4-7 \%$ of employees are exposed to potentially harmful levels of WBV [3]. Beside the effects on LBP [3-13], it is shown that WBV can alter the peripheral nervous system function, lead to visual and vestibular disturbances (motion sickness, dizziness, disturbed balance), as well as the prostate and gastrointestinal problems [14,15].

The increased muscle activity necessary to dampen

Received: May 2014, Accepted: November 2014

Correspondence to: Dragan D. Stamenković

Faculty of Mechanical Engineering,

Kraljice Marije 16, 11120 Belgrade 35, Serbia

E-mail: dstamenkovic@mas.bg.ac.rs

doi:10.5937/fmet1404297S

(C) Faculty of Mechanical Engineering, Belgrade. All rights reserved the vibration [16] lead to muscle fatigue which affects the neuromuscular coordination [17]. It is reported that decrease in balance due to WBV exposure can be a contributing factor to falls of operators while exiting the vehicles [18] and also one of the factors leading to quad bike loss of control events in agriculture [19].

Directive 2002/44/EC [20] defines WBV as "the mechanical vibration that, when transmitted to the whole body, entails risks to the health and safety of workers, in particular lower-back morbidity and trauma of the spine". The directive establishes the obligation of employers to assess the WBV. It defines daily exposure limit value standardised to an eight hour reference period as $1.15 \mathrm{~m} / \mathrm{s}^{2}$ and daily exposure action value standardised to an eight hour reference period as $0.5 \mathrm{~m} / \mathrm{s}^{2}$. Member state can, as alternative, choose a vibration dose value of $21 \mathrm{~m} / \mathrm{s}^{1.75}$ as a limit value, and $9.1 \mathrm{~m} / \mathrm{s}^{1.75}$ as an action value. If action values are exceeded, the employer is obligated to take the measures to reduce the exposure by introducing other working methods, choosing the appropriate work and auxiliary equipment, choosing the appropriate maintenance programme, changing the design and layout of workplaces and work stations, providing adequate training, limiting the duration and intensity of the exposure, accepting the appropriate work schedules with adequate rest periods and providing the clothing to protect exposed workers from cold and damp. The effects of vibration on interference with the proper handling of controls or reading of indicators are also the subject of this directive. Popović et al. [21] research the maintenance aspects by using risk-decision factors.

Figure 1 shows the WBV limit values defined in ISO 2631-1 [22]. This standard also defines the means to assess the WBV. It divides periodic, random and transient WBV in two groups according to frequency range: $0.5-80 \mathrm{~Hz}$ and $0.1-0.5 \mathrm{~Hz}$, the first group being influential on health, and the second on motion sickness. 


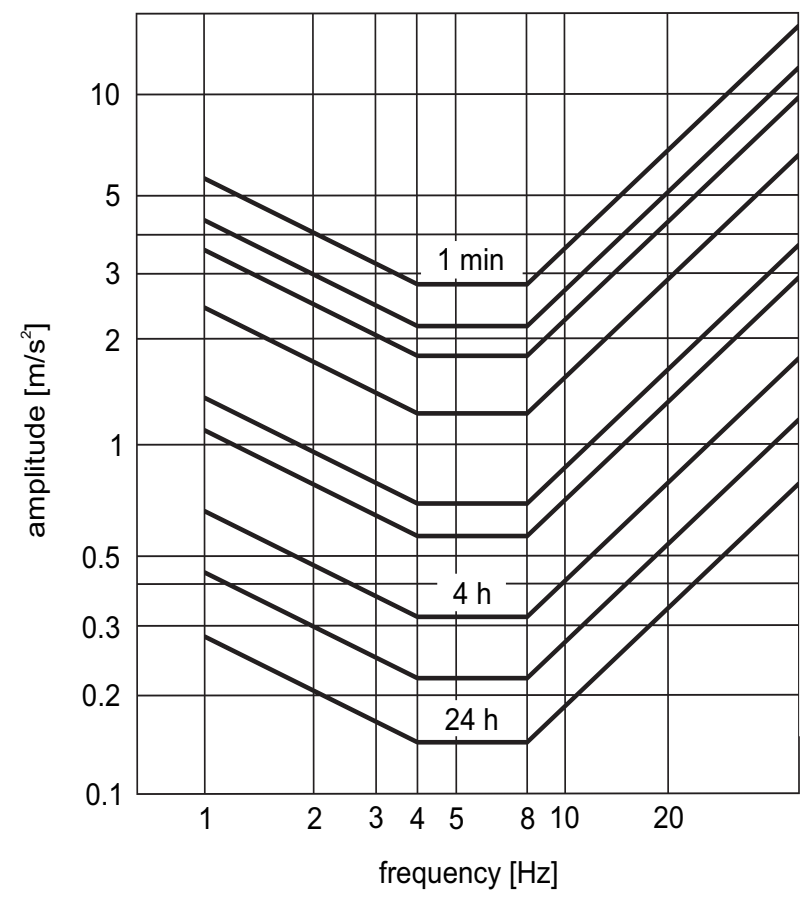

Figure 1. Exposure limits as defined by ISO 2631-1 [22]

\section{NEGATIVE EFFECTS OF WBV ON REACTION TIMES}

In addition to potentially serious health consequences related to prolonged exposure to $\mathrm{WBV}$, fatigue is another aspect studied by many authors [23-25]. However, WBV have not only health and fatigue consequences, it has been documented that reaction times are also influenced. The time between stimulus and response is composed of time needed for mental operations and time needed for physical operations [26], and WBV can prolong the reaction time by acting on both the mental and the physical abilities.

Previous studies [27-30] clearly demonstrate negative effects of WBV on various aspects of cognitive performance, memory and learning.

In one of the studies [31], the individual and combined effects of noise and WBV at various intensity levels on cognitive performance and subjective experience of 55 subjects were examined. During each environmental exposure, short-term memory performance was tested with a visual Sternberg paradigm. After each environmental exposure, subjects rated the difficulty of the task and the annoyance level of the exposure. The results of this study showed that there is no significant effect of environmental exposure on reaction times. However, subjects rated annoyance in vibration conditions as 2.44 out of 10 , with standard deviation (SD) of 1.61. This is compared to 0.93 (SD 1.26 ) with no vibration, and difficulty as 2.88 (SD 1.14) compared to 2.22 (SD 1.65).

It is shown that WBV of $16 \mathrm{~Hz}$ frequency and $1 \mathrm{~m} / \mathrm{s}^{2}$ amplitude significantly decreases short-term memory performance [29]. WBV can also change the sensitivity of proprioceptive organs, causing neuro-motor habituation or adaptation [32-35]. The acute effects of WBV on directionality and reaction time latency of trunk muscles were the subject of one study [36], and the results emphasised the importance of rest. An increase of electromyography latency of trunk muscles for $68.7 \mathrm{~ms}$ on average was measured in the vibration condition compared to non-vibration condition.

Another study [37] investigated the influence of different sitting postures during work on reaction time and perceived workload of 21 subjects exposed to 1-20 $\mathrm{Hz}$ random WBV in vertical and longitudinal directions. Subjects had to complete a choice reaction time task while seated in different posture conditions and NASA task load index workload assessment after the task. Measured mean reaction time during vibration was 700 $\mathrm{ms}$ compared to $555 \mathrm{~ms}$ in non-vibration condition with no armrest in upright seating position and $625 \mathrm{~ms}$ compared to $575 \mathrm{~ms}$ with armrest in upright seating position.

\section{REACTION TIME STUDIES}

\subsection{Aim and objectives}

Following such an overwhelming evidence of negative consequences of WBV, a research programme has been devised to better understand WBV influence on safety. Initially, the aim was set to investigate how WBV of four different frequencies $(1,5,20$ and $50 \mathrm{~Hz})$ affect the reaction time to sound and visual stimuli. To provide a reference reaction time values, reaction times were measured with subject not exposed to WBV.

The frequencies were selected to cover a wide range, with particular attention on $5 \mathrm{~Hz}$, since previous studies [38-40] found primary resonance frequency of seated subject in the range of 4 to $6 \mathrm{~Hz}$.

The reaction time measurements also included another test, when subjects were not exposed to WBV but have just consumed one alcoholic drink.

\subsection{Equipment}

For the purpose of this study, a dedicated test stand was designed and built, as schematically shown in Figure 2. It consists of a seating platform with mechanical vibration exciter. Audio and visual stimuli are provided using computer monitor and headphones, with the reaction exerted over a hand command. An accelerometer mounted within the seat, combined with a control and acquisition systems, ensured that desired frequencies and amplitudes are achieved.

The subject is seated in upright position with no backrest or armrest, and with legs hanging. When needed, sinusoidal vibration was exerted on sitting platform by mechanical exciter shown in Figure 3 . It consists of a frame (1), electric motor (2) powering the flywheels (3) via belt (4). Force transducer (5) was used in the process of rig development but is was concluded that this signal is not required during the tests. Frequency regulator (6) was used to change the angular velocity of the motor, which determined the vibration frequency, while the amplitude was set by changing the imbalance masses attached to the flywheels.

Once set-up, the control of the rig was entirely automatic, from generating visual and sound stimuli to measuring and recording reaction times. 


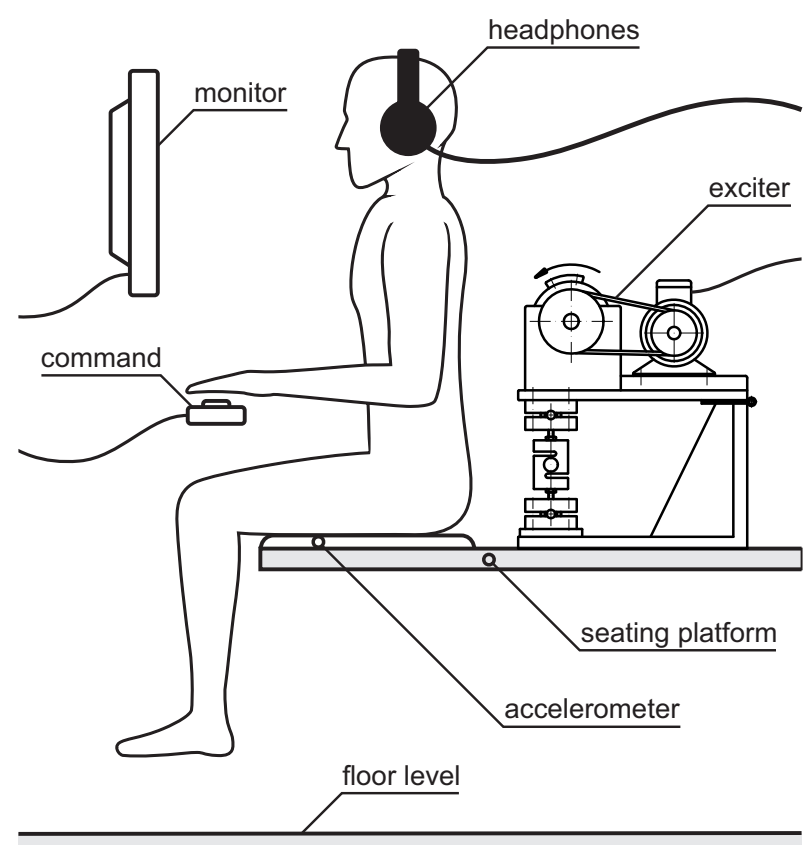

Figure 2. Schematic diagram of test installation

\subsection{Methodology}

The experiments were set up to measure the reaction times when the subject is exposed to:

1. sound stimuli;

2. visual stimuli.

In both cases, the following test conditions were simulated:

a. The subject is not exposed to WBV;

b.-e. The subject is exposed to four discrete frequencies of 1, 5, 20 and $50 \mathrm{~Hz}$. In all four cases the vibration amplitude was set to 2.4 $\mathrm{m} / \mathrm{s}^{2} \mathrm{rms}$;

f. the subject is not exposed to WBV but has just consumed $0.3 \mathrm{ml}$ of alcohol per $1 \mathrm{~kg}$ of body mass (approximately one alcoholic drink).

Subjects were asked to come to the laboratory twelve mornings in a row and take a 30 minutes long test, the sequence being as follows: $0 \mathrm{~Hz}$ audio, $1 \mathrm{~Hz}$ audio, $5 \mathrm{~Hz}$ audio, $20 \mathrm{~Hz}$ audio, $50 \mathrm{~Hz}$ audio, alcohol audio, $0 \mathrm{~Hz}$ visual, $1 \mathrm{~Hz}$ visual, $5 \mathrm{~Hz}$ visual, $20 \mathrm{~Hz}$ visual, $50 \mathrm{~Hz}$ visual, alcohol visual.

Reaction times to 5 consecutive audio or visual stimuli were measured at the start of every 30 minutes long period and afterwards at the end of every minute. The values were obtained as the time needed for subject to react - press the hand command (a button) after a stimulus (audio or visual) was given.

\subsection{Sound and visual stimuli}

Sound stimulus was based on a guidelines [41] - a triangle wave sound with a frequency of $500 \mathrm{~Hz}$ and intensity level of $100 \mathrm{~dB}(\mathrm{~A})$ was emitted. Audio signals were transmitted to the subjects through the headphones.

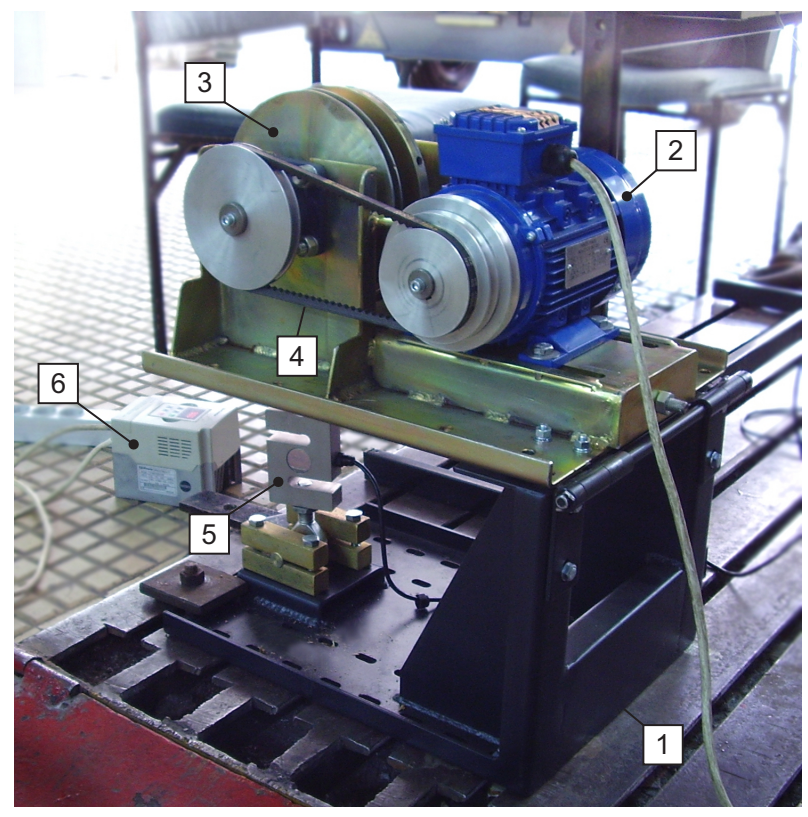

Figure 3. Vibration exciter

Visual stimulus consisted of changing the colour of full 15" monitor screen at a distance of half a metre from subject's eyes from black (RGB: $0,0,0)$ to green (RGB: 0, 255, 0). During the visual stimuli tests, subjects were equipped with the noise-protection headset to exclude the effects of noise arising from the exciter.

\subsection{Subjects}

Experiment was conducted on fifty healthy male subjects, all students of mechanical engineering. The main characteristics can be summarised as:

- Mean age: 21.8 years (standard deviation 1.6);

- Mean weight: $80.7 \mathrm{~kg}$ (standard deviation 8.1);

- Mean height: $179.9 \mathrm{~cm}$ (standard deviation 5.9). All subjects were informed of the experimental protocol and potential risks. They were all volunteers and could leave the experiment at any time (though all stayed throughout the tests).

\section{RESULTS}

\subsection{Reaction times to audio stimulus}

Table 1 shows mean reaction times and standard deviation values at the beginning $(0 \mathrm{~min})$, in the middle (15 min) and at the end (30 min) of every audio test. The results are graphically presented in Figure 4.

The obtained reaction times and trends are very consistent - the influence of fatigue (elapsed time) and frequencies is very pronounced.

When comparing the change in reaction time with elapsed time, across all frequencies, the trends are consistent. Reaction times increase due to fatigue. For example, with no WBV $(0 \mathrm{~Hz})$, initially the average reaction time is $277 \mathrm{~ms}$, which increase to $282 \mathrm{~ms}$ after 15 minutes, then to $288 \mathrm{~ms}$ after 30 minutes. This represents an increase of the reaction time by $11 \mathrm{~ms}$ after 30 minutes. During the same period, at $1 \mathrm{~Hz} \mathrm{WBV}$, 
increase is more pronounced, at $38 \mathrm{~ms}$ (from 289 to 327 $\mathrm{ms})$. At $5 \mathrm{~Hz} \mathrm{WBV}$, the increase is similar but only slightly lower at $35 \mathrm{~ms}$ (from 325 to $360 \mathrm{~ms}$ ). At $20 \mathrm{~Hz}$ $\mathrm{WBV}$, the increase in average reaction time remains at $35 \mathrm{~ms}$ (from 310 to 345 ), and only slightly increases at $50 \mathrm{~Hz} \mathrm{WBV}$, to $36 \mathrm{~ms}$ (from 301 to 337 ).

As regard to standard deviation values, they also increase with the elapsed time, the lowest being at $0 \mathrm{~Hz}$, with only $2 \mathrm{~ms}$ increase (from $35 \mathrm{~ms}$ to $37 \mathrm{~ms}$ ) within 30 minutes period. The standard deviation values increase initially become larger at higher WBV frequencies, at $1 \mathrm{~Hz}$ by $24 \mathrm{~ms}$ (from $39 \mathrm{~ms}$ to $63 \mathrm{~ms}$ ) reaching highest increase at $5 \mathrm{~Hz}$, at $29 \mathrm{~ms}$ from $66 \mathrm{~ms}$ at the beginning of the test, to $95 \mathrm{~ms}$ at the end. At higher frequencies, the increase is more moderate and very similar, at $20 \mathrm{~Hz}$ standard deviation increase is 23 $\mathrm{ms}$ (from $51 \mathrm{~ms}$ to $74 \mathrm{~ms}$ ) and at $50 \mathrm{~Hz}$ an increase of $24 \mathrm{~ms}$ is recorded (from $43 \mathrm{~ms}$ to $67 \mathrm{~ms}$ ).

When comparing reaction times at different frequencies, $0 \mathrm{~Hz}$ clearly shows shortest times at $277 \mathrm{~ms}$ average, at the beginning of the tests. This increases by $12 \mathrm{~ms}$ at $1 \mathrm{~Hz}$, then by further $36 \mathrm{~ms}$ at $5 \mathrm{~Hz}$, then drops by $15 \mathrm{~ms}$ at $20 \mathrm{~Hz}$, and further $9 \mathrm{~ms}$ at $50 \mathrm{~Hz}$. That means, when comparing with no vibration, the increase in reaction time is $48 \mathrm{~ms}$ at $5 \mathrm{~Hz}$, and $24 \mathrm{~ms}$ at $50 \mathrm{~Hz}$. The differences are even more pronounced as time elapses, at the end, after 30 minutes, at $1 \mathrm{~Hz}$ WBV the increase is $39 \mathrm{~ms}$ when compared to no vibrations. Again, the highest difference (to no vibration) is recorded in relation to the $5 \mathrm{~Hz}$, being $72 \mathrm{~ms}$.

Similarly, standard deviation values are lowest at no vibration tests and highest at $5 \mathrm{~Hz}$, with the differences being $31 \mathrm{~ms}$ higher at the beginning of the tests (being $35 \mathrm{~ms}$ and $66 \mathrm{~ms}$ respectively). The difference increases to $58 \mathrm{~ms}$ at the end of the test (being $37 \mathrm{~ms}$ and $95 \mathrm{~ms}$ respectively).

Interestingly, the increase in reaction time during 30 minutes tests, is smallest after the consumption of alcohol, by only $5 \mathrm{~ms}$, from 285 to $290 \mathrm{~ms}$. These are relatively small increases when compared to the no vibration tests results when no alcohol is being consumed $(0 \mathrm{~Hz})$. At the beginning of the test the increase is $8 \mathrm{~ms}$ (being $277 \mathrm{~ms}$ and $285 \mathrm{~ms}$ respectively), which reduces to only $2 \mathrm{~ms}$ after 30 minutes (being 288 and $290 \mathrm{~ms}$ respectively). Standard deviation values are practically identical for both cases. Such small differences can be explained in various ways - they might be simply the result of particular concentration of subjects, aiming to perform 'at best', knowing that they have consumed alcohol and are being monitored. It is important to point out that the measurements were only conducted with no vibrations.

\subsection{Reaction times to visual stimulus}

Mean reaction times and standard deviation values for visual stimulus tests are presented in Table 2 and Figure 5. The trends are very similar to audio stimuli, the shortest reaction times and standard deviation values being achieved at no vibration tests $(0 \mathrm{~Hz})$ and the highest at $5 \mathrm{~Hz}$. Again, reaction times increase with elapsed time for all frequencies.
Specifically, at no vibration $(0 \mathrm{~Hz})$, the average reaction time is initially $209 \mathrm{~ms}$, increasing to $212 \mathrm{~ms}$ after 15 minutes and to $222 \mathrm{~ms}$ after 30 minutes. That means an increase of $13 \mathrm{~ms}$ from the start to the end of the test at this condition. The increase during test at $1 \mathrm{~Hz}$ is identical, being also $13 \mathrm{~ms}$, though the corresponding values are higher, 219 and $232 \mathrm{~ms}$. Increase is more pronounced at $5 \mathrm{~Hz}$, the increase is 19 $\mathrm{ms}$, from 255 to $274 \mathrm{~ms}$. At $20 \mathrm{~Hz}$, the average reaction time increases from $232 \mathrm{~ms}$ at the beginning of the test to $257 \mathrm{~ms}$ at the end, an increase of $25 \mathrm{~ms}$. At $50 \mathrm{~Hz}$, the increase is lower, being $18 \mathrm{~ms}$, from 220 to $238 \mathrm{~ms}$.

Corresponding standard deviation values also increase with elapsed time, by $6 \mathrm{~ms}$ at no vibration (from 26 to $32 \mathrm{~ms}$ ), by $4 \mathrm{~ms}$ (from 32 to $36 \mathrm{~ms}$ ) at $1 \mathrm{~Hz}$, $15 \mathrm{~ms}$ at $5 \mathrm{~Hz}$ (from 52 to $67 \mathrm{~ms}$ ). The changes are then less pronounced at higher frequencies, being $8 \mathrm{~ms}$ at 20 $\mathrm{Hz}$ (47 and $55 \mathrm{~ms}$ respectively) and $6 \mathrm{~ms}$ at $50 \mathrm{~Hz}$ (41 and $47 \mathrm{~ms}$ respectively).

When comparing reaction times between frequencies (at identical elapsed times), the results are similar to the audio stimuli, the shortest times are for no vibrations $(0$ $\mathrm{Hz}$ ) and longest for $5 \mathrm{~Hz}$. At the beginning of the tests ( 0 minutes) the increase is $46 \mathrm{~ms}$ (from 209 to $255 \mathrm{~ms}$ ), becoming even higher at $52 \mathrm{~ms}$ at the end of elapsed time (30 minutes), rising from $222 \mathrm{~ms}$ to $274 \mathrm{~ms}$.

Corresponding standard deviation values are again lowest at $0 \mathrm{~Hz}$ and highest at $5 \mathrm{~Hz}$, being about twice higher at $5 \mathrm{~Hz}$.

Interestingly, the increase in reaction time during 30 minutes tests, is smallest after the consumption of alcohol, by only $3 \mathrm{~ms}$, from 223 to $226 \mathrm{~ms}$. However, the average reaction times are longer when compared to the no vibration tests results when no alcohol is being consumed $(0 \mathrm{~Hz})$. At the beginning of the test the increase is $14 \mathrm{~ms}$ (being $209 \mathrm{~ms}$ and $223 \mathrm{~ms}$ respectively), which reduces to only $4 \mathrm{~ms}$ after 30 minutes (being 222 and $226 \mathrm{~ms}$ respectively). Standard deviation values are practically identical for both cases. In general, the results are very similar to the audio stimuli and can be explained in similar ways.

\subsection{Reaction times: audio vs. visual stimuli}

Reaction times showed very similar patterns for both audio and visual stimuli. The shortest times were measured when subjects were not exposed to vibrations $(0 \mathrm{~Hz})$ and the longest when the seating platform was vibrating at $5 \mathrm{~Hz}$. In all cases, average reaction times increased with elapsed time. Standard deviation values closely followed such patterns.

When comparing corresponding average response times to audio and visual stimuli, the response to visual stimuli are shorter. This is true for all cases, thought there are some variations in actual values, the differences are quite pronounce, being typically between 60 and $100 \mathrm{~ms}$. Interestingly, reaction times to visual stimuli at the beginning of tests ( 0 minutes) is 70 to $80 \mathrm{~ms}$ shorter for all frequencies. At the end of the test, after 30 minutes, the differences are most pronounced at about 80 to $100 \mathrm{~ms}$, with the slight exception of no vibration case $(0 \mathrm{~Hz})$. In this condition, the reaction time to visual stimulus is only $66 \mathrm{~ms}$ shorter 
than for audio stimulus. Standard deviation values are also smaller for visual stimuli, typically over $20 \mathrm{~ms}$, except, again for $0 \mathrm{~Hz}$, when the differences are smaller, with $9 \mathrm{~ms}$ difference at the beginning ( $26 \mathrm{vs} .35 \mathrm{~ms}$ ) and $5 \mathrm{~ms}$ at the end of the test ( $32 \mathrm{vs} .37 \mathrm{~ms}$ ).

The effects of alcohol to reaction times were studied before [42] and in this study it was decided to compare them to the effects of WBV. Measured reaction times after consumption of alcohol, when compared to equivalent tests, follow patterns similar to the above described. Both, reaction times and standard deviation values are shorter for visual stimuli.

\section{CONCLUSIONS}

Conducted research clearly demonstrates an increase in reaction times with exposure to vibrations. The best, shortest reaction times for both sound and visual stimuli were measured for no vibration of the seating platform, with the most detrimental influence being observed at vibration frequency of $5 \mathrm{~Hz}$. This indicates that most dangerous frequencies are those close to the human body resonance frequencies.

At every frequency, reaction times increased with prolonged exposure. With no exception, the shortest reaction times were measured at the beginning of tests and the longest at the end, after 30 minutes.

The increase in reaction times with elapsed time was typically more pronounced when subjects were exposed to sound stimuli. Equally, under the same conditions, reaction times to sound stimuli were longer than to visual stimuli.

In all cases, changes in standard deviation values follow the same pattern as average reaction times. Subjects tended to make more mistakes producing the reaction times exceeding the mean values up to three times, when exposed to vibration. This can be highly dangerous, since during the operation of machinery or vehicle, one mistake, one late reaction, can be enough to produce the accident with possible tragic outcomes, affecting not only the operator/driver.

The study shows the importance of reducing whole body vibration in improving reaction times of the drivers and operators. It is typically difficult to quantify the influence of increased reaction times on actual vehicle operation but one simple example can be used to illustrate potential dangers. For example, the biggest overall difference in reaction time to the stimuli of the same nature was $83 \mathrm{~ms}$ for sound stimuli $(277 \mathrm{~ms}$ at the beginning of the test at $0 \mathrm{~Hz}$ and $360 \mathrm{~ms}$ at the end of the test at $5 \mathrm{~Hz}$ ). If the driver is to take an evasive action (braking or steering) whilst driving on the motorway at the speed of $130 \mathrm{~km} / \mathrm{h}$, this corresponds to a covered distance of $2.77 \mathrm{~m}$. Such a distance can be very important in preventing an accident or reducing the consequences. It should be taken into consideration that the time of exposure was relatively short (30 minutes). Moreover, all subjects were young, healthy and fit.

In relative terms, the increase in reaction times can be probably best illustrated in the following manner:

- Within the vibrations of the same frequency and stimulus method, the increase is typically about 5 to $10 \%$ within 30 minutes test.

- Within the same time periods, differences between $0 \mathrm{~Hz}$ and $5 \mathrm{~Hz}$ are most pronounced, being in the order of $25 \%$

- Maximum increase in average reaction time has been measured between 'visual, $0 \mathrm{~Hz}, 0 \mathrm{~min}$ ' and 'audio, $5 \mathrm{~Hz}, 30 \mathrm{~min}$ ', being as high as $72 \%$.

The influence of alcohol was not of mainstream importance of the research conducted. Nevertheless, the measurements conducted only without vibration showed relatively modest but consistent increase of response times. It is important pointing out that the reaction times are only one measure of safe driving. It is well established that alcohol consumption is detrimental to the ability to analyse and judge situations (in particular sudden critical changes in circumstances), the ability to conduct complex manoeuvres safely, at the same time increasing the intent of taking higher risks.

Further investigation can be focused on optimising the vehicle suspension system [43-45] (whether it is passive, semi-active or active) to reduce the WBV in general, or to attenuate the chosen frequencies of WBV. Another direction for further investigation is to study the effects of vibration distribution on operator's body taking into account arm and leg vibration, as body parts have different resonance frequencies and can influence the driver/operator activities and fatigue in different ways.

\section{ACKNOWLEDGMENT}

This paper presents some of the results obtained through two projects supported by Serbian Ministry of Education, Science and Technological Development (TR 35045 - "Scientific-Technological Support to Enhancing the Safety of Special Road and Rail Vehicles" and TR 35040 - "Developed New Methods for Diagnosis and Examination of Mechanical Structures"). The authors express their gratitude for this assistance and are also appreciative to help received from the colleagues and students in conducting the research studies.

Table 1. Test results - Reaction times to sound stimulus

\begin{tabular}{|c|c|c|c|c|c|c|c|}
\hline \multirow{2}{*}{$\begin{array}{c}\text { Elapsed time } \\
\boldsymbol{t}_{\mathbf{t}}[\mathrm{min}]\end{array}$} & $\begin{array}{c}\text { Reaction time } \\
\boldsymbol{t}_{\mathbf{r}}[\mathrm{ms}]\end{array}$ & \multicolumn{6}{|c|}{ Seating platform vibration frequency $\boldsymbol{f}[\mathrm{Hz}]$} \\
\cline { 3 - 9 } & $\mathbf{0}$ & $\mathbf{1}$ & $\mathbf{5}$ & $\mathbf{2 0}$ & $\mathbf{5 0}$ & $\mathbf{0}($ Alc.) \\
\hline \multirow{2}{*}{$\mathbf{0}$} & average & 277 & 289 & 325 & 310 & 301 & 285 \\
\cline { 2 - 9 } & standard deviation & 35 & 39 & 66 & 51 & 43 & 35 \\
\hline \multirow{2}{*}{$\mathbf{1 5}$} & average & 282 & 306 & 342 & 328 & 318 & 286 \\
\cline { 2 - 9 } & standard deviation & 35 & 49 & 75 & 59 & 57 & 36 \\
\hline \multirow{2}{*}{30} & average & 288 & 327 & 360 & 345 & 337 & 290 \\
\cline { 2 - 9 } & standard deviation & 37 & 63 & 95 & 74 & 67 & 38 \\
\hline
\end{tabular}


Table 2. Test results - Reaction times to visual stimulus

\begin{tabular}{|c|c|c|c|c|c|c|c|}
\hline \multirow{2}{*}{$\begin{array}{c}\text { Elapsed time } \\
\boldsymbol{t}_{\mathbf{t}}[\mathrm{min}]\end{array}$} & $\begin{array}{c}\text { Reaction time } \\
\boldsymbol{t}_{\mathbf{r}}[\mathrm{ms}]\end{array}$ & \multicolumn{6}{|c|}{ Seating platform vibration frequency $\boldsymbol{f}[\mathrm{Hz}]$} \\
\cline { 3 - 9 } & $\mathbf{0}$ & $\mathbf{1}$ & $\mathbf{5}$ & $\mathbf{2 0}$ & $\mathbf{5 0}$ & $\mathbf{0}($ Alc. $)$ \\
\hline \multirow{3}{*}{$\mathbf{0}$} & average & 209 & 219 & 255 & 232 & 220 & 223 \\
\cline { 2 - 9 } & standard deviation & 26 & 32 & 52 & 47 & 41 & 25 \\
\hline \multirow{2}{*}{$\mathbf{3 0}$} & average & 212 & 225 & 263 & 248 & 235 & 225 \\
\cline { 2 - 9 } & standard deviation & 27 & 33 & 58 & 55 & 43 & 27 \\
\hline & average & 222 & 232 & 274 & 257 & 238 & 226 \\
\hline
\end{tabular}

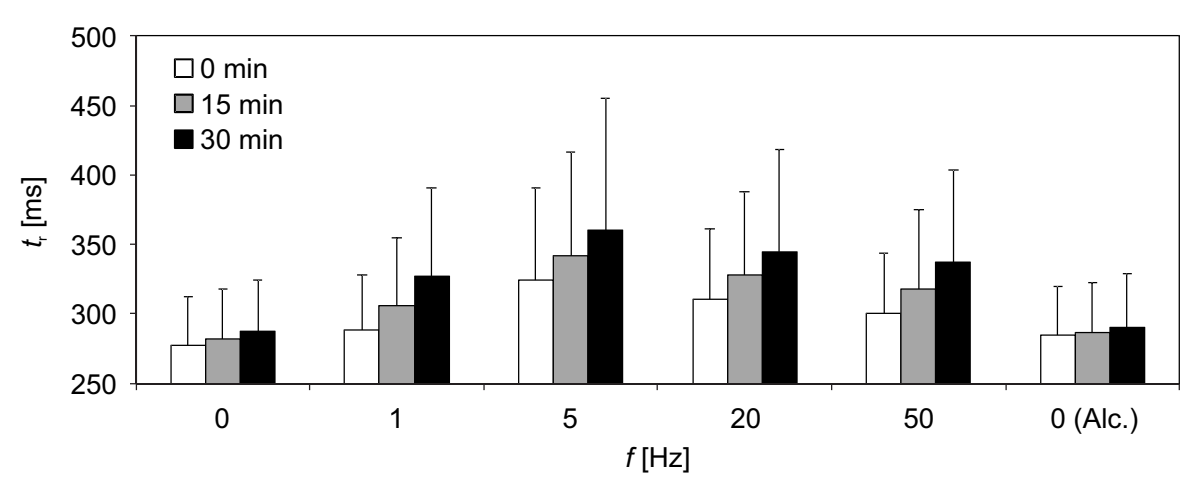

Figure 4. Mean reaction times to sound stimuli stimulus

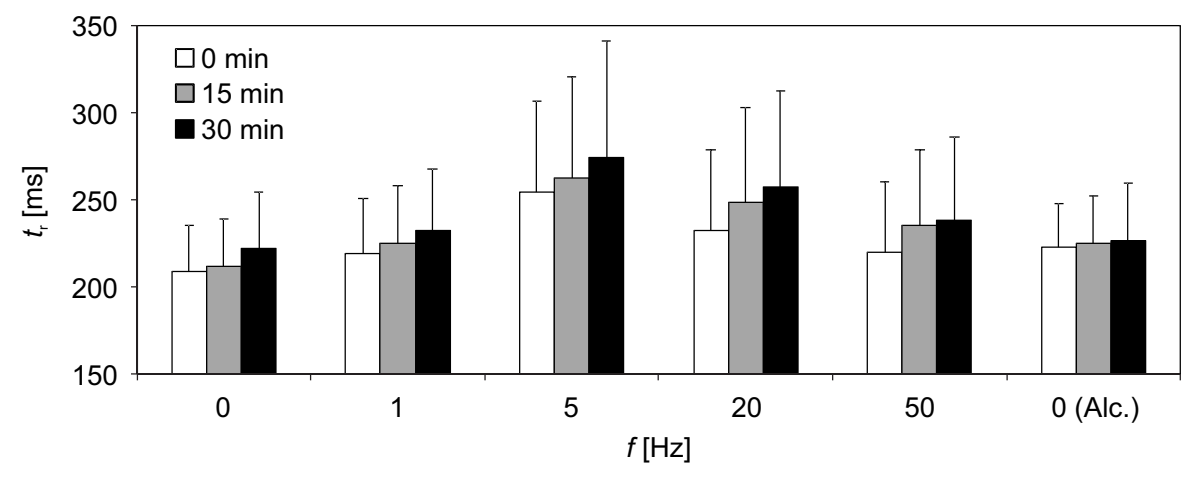

Figure 5. Mean reaction times to visual stimuli stimulus

\section{REFERENCES}

[1] Albasini, A., Krause, M. and Rembitzki, I.V.: Using whole body vibration in physical therapy and sport: Clinical practice and treatment exercises, Churchill Livingstone, Edinburgh, 2010.

[2] Rusinski, E., Moczko, P., Odyjas, P. and Pietrusiak, D.: Investigations of structural vibrations problems of high performance machines, FME Transactions, Vol. 41, No. 4, pp. 305-310, 2013.

[3] Department of Health and Human Services: Musculoskeletal disorders and workplace factors, Cincinnati, 1997.

[4] Cross, J. and Walters, M.: Vibration and jarring as a cause of back injury in the NSW coal mining industry, Safety Sci., Vol. 17, No. 4, pp. 269-274, 1994.

[5] Griffin, M.J.: Handbook of human vibration, Academic Press, London, 1990.

[6] Hansson, T., Magnusson, M. and Broman, H.: Back muscle fatigue and seated whole body vibrations:
An experimental study in man, Clin. Biomech., Vol. 6, No. 3, pp. 173-178, 1991.

[7] Hulshof, C. and Van Zanten, B.V.: Whole-body vibration and low-back pain, Int. Arch. Occup. Environ. Health, Vol. 59, No. 3, pp. 205-220, 1987.

[8] Johanning, E., Wilder, D.G., Landrigan, P.J. and Pope, M.H.: Whole-body vibration exposure in subway cars and review of adverse health effects, J. Occup. Med., Vol. 33, No. 5, pp. 605-612, 1991.

[9] Lings, S. and Leboeuf-Yde, C.: Whole-body vibration and low back pain: A systematic, critical review of the epidemiological literature 1992-1999, Int. Arch. Occup. Environ. Health, Vol. 73, No. 5, pp. 290-297, 2000.

[10] Lis, A.M., Black, K.M., Korn, H. and Nordin, M.: Association between sitting and occupational LBP, Eur. Spine J., Vol. 16, No. 2, pp. 283-298, 2007.

[11] Magnusson, M.L., Pope, M.H., Wilder, D.G. and Areskoug, B.: Are occupational drivers at an increased risk for developing musculoskeletal disorders?, Spine, Vol. 21, No. 6, pp. 710-717, 1996. 
[12] Seidel, H.: Selected health risks caused by longterm, whole-body vibration, Am. J. Ind. Med., Vol. 23, No. 4, pp. 589-604, 1993.

[13] Wikström, B.-O., Kjellberg, A. and Landström, U.: Health effects of long-term occupational exposure to whole-body vibration: A review, Int. J. Ind. Ergonom., Vol. 14, No. 4, pp. 273-292, 1994.

[14] Bonney, R.A.: Human responses to vibration: Principles and methods, in: Wilson, J.R. and Corlett, E.N. (Eds.): Evaluation of Human Work - A Practical Ergonomics Methodology ( $2^{\text {nd }}$ ed), Taylor and Francis, London, pp. 541-556, 1995.

[15] Miyashita, K., Morioka, I., Tanabe, T., Iwata, H. and Takeda, S.: Symptoms of construction workers exposed to whole body vibration and local vibration, Int. Arch. Occup. Environ. Health, Vol. 64, No. 5, pp. 347-351, 1992.

[16] Wakeling, J.M. and Nigg, B.M.: Modification of soft tissue vibrations in the leg by muscular activity, J. Appl. Physiol., Vol. 90, No. 2, pp. 412420, 2001.

[17] Ng, J.K.-F., Parnianpour, M., Richardson, C.A. and Kippers, V.: Effect of fatigue on torque output and electromyographic measures of trunk muscles during isometric axial rotation, Arch. Phys. Med. Rehab., Vol. 84, No. 3, pp. 374-381, 2003.

[18] Nicholson, A.S. and David, G.C.: Slipping, tripping and falling accidents to delivery drivers, Ergonomics, Vol. 28, No. 7, pp. 977-991, 1985.

[19] Milosavljevic, S., McBride, D.I., Bagheri, N., Vasiljev, R.M., Carman, A.B., Rehn, B. and Moore, D.: Factors associated with quad bike loss of control events in agriculture, Int. J. Ind. Ergonom., Vol. 41, No. 3, pp. 317-321, 2011.

[20] The European parliament and the Council of the European Union: Directive 2002/44/EC of the European parliament and of the Council of 25 June 2002 on the minimum health and safety requirements regarding the exposure of workers to the risks arising from physical agents (vibration), Official Journal of the European Communities, pp. L177/13-L177/19, 2002.

[21] Popović, V., Vasić, B. and Stanojević, N.: Options for the choice of maintenance concept using riskdecision factors, in: Proceedings of the Euromaintenance Conference, 12-14.05.2010, Verona, pp. 93-97.

[22] International Organization for Standardization: ISO 2631-1: Mechanical vibration and shock Evaluation of human exposure to whole-body vibration - Part 1: General requirements, Geneva, 1997.

[23] Tian, L.G., Gang, W.L., Ping, H.J., Ji, L.C. and Fang, L.Y.: Investigation of eyestrain and working capacity for female crane operators, Int. J. Ind. Ergonom., Vol. 18, No. 2-3, pp. 221-224, 1996.

[24] Granata, K.P., Slota, G.P. and Wilson, S.E.: Influence of fatigue in neuromuscular control of spinal stability, Hum. Factors, Vol. 46, No. 1, pp. 81-91, 2004.
[25] Wilder, D.G., Aleksiev, A.R., Magnusson, M.L., Pope, M.H., Spratt, K.F. and Goel, V.K.: Muscular response to sudden load: A tool to evaluate fatigue and rehabilitation, Spine, Vol. 21, No. 22, pp. 26282639, 1996.

[26] Sternberg, S.: Memory-scanning: Mental processes revealed by reaction-time experiments, Am. Sci., Vol. 57, No. 4, pp. 421-457, 1969.

[27] Harris, C.S. and Shoenberger, R.W.: Combined effects of broadband noise and complex waveform vibration on cognitive performance, Aviat. Space Envir. Md., Vol. 51, No. 1, pp. 1-5, 1980.

[28] Sandover, J. and Champion, D.F.: Some effects of a combined noise and vibration environment on a mental arithmetic task, J. Sound Vib., Vol. 95, No. 2, pp. 203-212, 1984.

[29] Sherwood, N. and Griffin, M.J.: Effects of wholebody vibration on short-term memory, Aviat. Space Envir. Md., Vol. 61, No. 12, pp. 1092-1097, 1990.

[30] Sherwood, N. and Griffin, M.J.: Evidence of impaired learning during whole-body vibration, J. Sound Vib., Vol. 152, No. 2, pp. 219-225, 1992.

[31] Ljungberg, J., Neely, G. and Lundström, R.: Cognitive performance and subjective experience during combined exposures to whole-body vibration and noise, Int. Arch. Occup. Environ. Health, Vol. 77, No. 3, pp. 217-221, 2004.

[32] Cordo, P., Gurfinkel, V.S., Bevan, L. and Kerr, G.K.: Proprioceptive consequences of tendon vibration during movement, J. Neurophysiol., Vol. 74, No. 4, pp. 1675-1688, 1995.

[33] Roll, J.P. and Vedel, J.P.: Kinaesthetic role of muscle afferents in man, studied by tendon vibration and microneurography, Exp. Brain Res., Vol. 47, No. 2, pp. 177-190, 1982.

[34] Shinohara, M.: Effects of prolonged vibration on motor unit activity and motor performance, Med. Sci. Sports Exerc., Vol. 37, No. 12, 2120-2125, 2005.

[35] Wierzbicka, M.M., Gilhodes, J.C. and Roll, J.P.: Vibration-induced postural posteffects, J. Neurophysiol., Vol. 79, No. 1, pp. 143-150, 1998.

[36] Arora, N. and Grenier, S.G.: Acute effects of whole body vibration on directionality and reaction time latency of trunk muscles: The importance of rest and implications for spine stability, J. Electromyogr. Kinesiol., Vol. 23, No. 2, pp. 394401, 2013.

[37] Newell, G.S. and Mansfield, N.J.: Evaluation of reaction time performance and subjective workload during whole-body vibration exposure while seated in upright and twisted postures with and without armrests, Int. J. Ind. Ergonom., Vol. 38, No. 5-6, pp. 499-508, 2008.

[38] Dewangan, K.N., Shahmir, A., Rakheja, S. and Marcotte, P.: Seated body apparent mass response to vertical whole body vibration: Gender and anthropometric effects, Int. J. Ind. Ergonom., Vol. 43, No. 4, pp. 375-391, 2013. 
[39] International Organization for Standardization: ISO 5982: Mechanical vibration and shock - Range of idealized values to characterize seated-body biodynamic response under vertical vibration, Geneva, 2001.

[40] Rakheja, S., Dong, R.G., Patra, S., Boileau, P.-É., Marcotte, P. and Warren, C.: Biodynamics of the human body under whole-body vibration: Synthesis of the reported data, Int. J. Ind. Ergonom., Vol. 40, No. 6, pp. 710-732, 2010.

[41] Department of Defense: MIL-STD-1472G: Department of Defense design criteria standard Human engineering, Washington, 2012.

[42] Maylor, E.A. and Rabbitt, P.M.A.: Alcohol, reaction time and memory: A meta-analysis, Br. J. Psychol., Vol. 84, No. 3, pp. 301-317, 1993.

[43] Popović, V., Vasić, B., Petrović, M. and Mitić, S.: System approach to vehicle suspension system control in CAE environment, Strojniški Vestnik Journal of Mechanical Engineering, Vol. 57, No. 2, pp. 100-109, 2011.

[44] Popović, V. and Stamenković, D.: System approach to vehicle suspension system control in CAE environment, in: Liu, H., Gao, H. and Li, P. (Eds.): Handbook of Vehicle Suspension Control Systems, The Institution of Engineering and Technology, Stevenage, pp. 303-326, 2013.

[45] Stamenković, D., Popović, V. and Blagojević, I.: Active suspension system control using neural network model to reduce passengers' whole-body vibration, in: Proceedings of the FISITA 2014
World Automotive Congress, 02-06.06.2014, Maastricht, F2014-NVH-021.

\section{ПРОДУЖЕЊЕ ВРЕМЕНА РЕАКЦИЈЕ РУКОВАОЦА УЗРОКОВАНО ВИБРАЦИЈАМА ЦЕЛОГ ТЕЛА}

\section{Драган Д. Стаменковић, Владимир М. Поповић, Марко А. Тировић}

Утицај вибрација целог тела на време реакције анализиран је уз помоћ, за ову сврху направљеног, пробног стола са механичким побудним уређајем. Испитаници су излагани условима без вибрација и вибрацијама учестаности 1, 5, 20 и $50 \mathrm{~Hz}$. Најкраћа времена реакције, како на звучне тако и на визуелне побуде, измерена су у условима без вибрација. Најштетнији утицај је примећен у случају вибрација учестаности $5 \mathrm{~Hz}$, када се просечна времена реакције увећавају за 50 до $70 \mathrm{~ms}$. Најкраћа времена реакције измерена су на почецима тестова, а најдужа на њиховим завршецима. Продужење времена реакције са протицањем времена теста је израженије у случају звучних побуда. Такође, под истим условима, измерена времена реакције су дужа у случају звучне побуде у односу на визуелну побуду (у просеку за 60 до 100 ms). У свим случајевима, промена вредности стандардне девијације пратила је образац сличан обрасцу промене средњих вредности времена реакције. 